\title{
Cytokine Dysregulation in Chronic Kidney Disease: How Can We Treat It?
}

\author{
Juan Jesus Carrero Mahmut Ilker Yilmaz Bengt Lindholm Peter Stenvinkel
}

Divisions of Renal Medicine and Baxter Novum, Department of Clinical Science, Intervention and Technology, Karolinska Institutet, Stockholm, Sweden

\section{Key Words}

Chronic kidney disease $\cdot$ Cytokine $\cdot$ Inflammation ·

Interleukin · Mortality · Dialysis

\begin{abstract}
As the kidney is the major site for elimination of many cytokines, the delicate equilibrium of pro-inflammatory cytokines and their inhibitors is clearly dysregulated in chronic kidney disease (CKD) patients. The consequences of the altered immune response in uremia lead to a state of persistent inflammation which is highly prevalent among CKD patients and is linked to complications such as the development of protein-energy wasting and atherosclerotic vascular disease. The present review aims at reviewing this complex orchestration of uremic cytokines beyond the well-studied interleukin- 6 and tumor necrosis factor- $\alpha$. Finally, we update our current understanding on anti-inflammatory treatment strategies in CKD patients, including nutritional and lifestyle measurements, pharmacological intervention and specific anticytokine strategies targeting the dialytic procedure.
\end{abstract}

Copyright $\odot 2008$ S. Karger AG, Basel

\section{Introduction}

In the immune system, a complex orchestration of cytokines and other molecules act in a paracrine, autocrine or endocrine fashion to control the differentiation, pro- liferation and activity of immune cells. As the kidney is the major site for elimination of many of these cytokines, the delicate equilibrium of pro-inflammatory cytokines and their inhibitors is clearly dysregulated in chronic kidney disease $(\mathrm{CKD})$ patients $[1,2]$. The dialysis procedure [3] further stimulates circulating nuclear cells for cytokine production [4], making them respond more vigorously to exposure to endotoxins [5]. These consequences of the altered immune response in uremia lead to a state of persistent inflammation [6,7] which is highly prevalent among CKD patients and is linked to complications such as the development of protein-energy wasting (PEW) and atherosclerotic vascular disease [3, 8]. Inflammation, PEW and atherosclerosis often coexist in CKD [9], and each of these risk factors independently predicts outcome in these patients. In order to understand this complex orchestration, selected cytokines will be reviewed with regards to our current understanding of the uremic cytokine misbalance, as well as an updated status of current and future anti-cytokine strategies in CKD.

\section{Innate and Humoral Immune System: Keeping Homeostasis as a Principle}

The cytokine response to infection or injury is a wellcoordinated and precisely controlled process aimed at maintaining the body homeostasis. When addressing the

\section{KARGER}

Fax +4161306 1234

E-Mail karger@karger.ch

www.karger.com
(C) 2008 S. Karger AG, Basel

0253-5068/08/0263-0291\$24.50/0

Accessible online at:

www.karger.com/bpu
J.J. Carrero

Divisions of Renal Medicine and Baxter Novum

K56, Karolinska Institutet, University Hospital at Huddinge

SE-14186 Stockholm (Sweden)

Tel. +468585 82601, Fax +468585 83925, E-Mail juan.jesus.carrero@ki.se 
role of cytokines in the context of atherosclerosis and uremia, it is important to distinguish between local and systemic inflammation. Locally produced pro-inflammatory mediators with atherogenic activity include interleukin (IL)-8, IL-12, IL-18, tumor necrosis factor (TNF)$\alpha$ and interferon (IFN)- $\gamma$, and among systemic mediators and markers of inflammation IL- 6 and IL- 8 should be mentioned [10]. Cytokines are soluble proteins with low molecular weight that are produced in response to an antigen and other signals and function as chemical messengers regulating various aspects of the innate and humoral immune systems. They are produced by virtually all cells involved in innate and humoral immunity, but especially by $\mathrm{T}$ helper (Th) lymphocytes. CD4 T helper cells are classified into two distinct types. Th1 cells primarily produce several pro-inflammatory cytokines notably IFN- $\gamma$, IL-12 and TNF- $\alpha$, which promote cellular immunity, whereas Th2 cells secrete a different set of cytokines, primarily IL-4, IL-5, IL-10 and IL-6, which promote humoral immunity. There is a T regulatory cell (CD+/CD25) that produces IL-10 and is capable of down-regulating both Th1 and Th2 responses. Th1 cytokines stimulate the synthesis of nitric oxide and other inflammatory mediators, the functional activity of $\mathrm{T}$ cytotoxic cells, natural killer (NK) cells and activated macrophages, exerting altogether a pro-inflammatory action. On the other hand, Th2 cytokines inhibit macrophage activation, T cell proliferation and the production of pro-inflammatory cytokines, being therefore involved in anti-inflammatory processes. Th1 and Th2 responses are mutually inhibitory. Thus, IL-12 and IFN- $\gamma$ inhibit Th2, while IL- 4 and IL-10 inhibit Th1 cell activities $[10,11]$. Indeed, the balance between pro- and anti-inflammatory cytokines rather than the absolute amount might be crucial for the progression of the atherosclerotic lesion [12].

In order to properly understand the state of cytokine dysregulation that is present in the CKD patients, a number of considerations should be made involving cytokine measurements [13]. Firstly, most of the published studies concentrate on selected cytokines measured in plasma, culture supernatants or in association with circulating cells. However, cytokines are moving targets and counterbalanced by inhibitors or other cytokines with opposed effects. Secondly, cytokines rarely act alone because they stimulate a variety of cell types to produce and secrete other cytokines in a cascade fashion. Elevation of one cytokine immediately leads to up- or down-regulation of several others. As many of the effect of cytokines are local, not systemic, these paracrine effects of cytokines are hard to detect. Thirdly, pro- and anti-inflam- matory cytokines bind to specific cytokine carriers (such as $\alpha_{2}$-macroglobulin) and these different binding proteins may serve as extracellular cytokine reservoirs and protective shields against degradation of cytokines. Thus, one important aspect that needs to be taken into account when understanding these studies is that established immunoassays to detect these cytokines cannot usually distinguish between active proteins and those that are blocked by their specific inhibitors.

\section{Cytokine Dysregulation in Uremia: An Allostatic Condition}

CKD is characterized by allostasis, i.e. a chronic state of disordered homeostasis that allows survival of the patients only at the expense of well-being and poor outcome. It is generally believed that uremia per se, while generally suppressing $\mathrm{T}$ cell function is also associated with altered Th balance. While one study suggests a Th1 predominance under uremic conditions [14], another report indicates a Th2 prevalence [15]. Clearly, further studies are needed to determine if alterations in Th balance may predispose to alterations in cytokines that might be responsible for the increased CVD risk in ESRD. It seems, however, that during the interdialytic interval, the cytokine production from monocytes is normal, although these cells release large amounts of pro-inflammatory cytokines under stimulation [16].

As a recent report from our group has extensively reviewed the role of IL- 6 , TNF- $\alpha$ and IL-10 [13], these cytokines which will not be contemplated in the present review. Perhaps among those, IL- 6 may be the most studied cytokine in CKD, and it is becoming more apparent that this pro-inflammatory cytokine plays a key role in the pathogenesis of both PEW and atherosclerosis in the CKD and dialysis populations [17]. Some studies have recently tried to prospectively compare the predictive value of different inflammatory markers in dialysis patients. Two of them, one using receiver operator characteristics (ROC) curves [18] and one using multivariate modeling [19], showed that the predictive value of IL-6 levels was higher than that attributable to other molecules studied with regard to all-cause and cardiovascular mortality. Another recent comparative study based on ROC analysis also showed that the prediction power of the combined inflammatory burden of a number of commonly measured cytokines and adhesion molecules was identical to that provided by the sole measurement of IL- 6 [20]. These results were further confirmed in another Brazil- 
ian HD cohort [21]. Thus, as IL- 6 seems to be the best option for risk stratification in dialysis patients, particularly in the context of clinical studies, further studies are needed to compare the predictive value of different inflammatory biomarkers also in patients with mild to moderate CKD. However, in clinical practice the acutephase protein CRP is still the most commonly used biomarker of the degree of inflammation, and as CRP measurements are cheap, reliable and easily implanted, they are widely used in many countries around the world.

\section{Interleukin-18}

IL-18 is a pro-inflammatory cytokine formerly known as IFN- $\gamma$-inducing factor, which seems to be its primary immune action [22]. While IL-18 mRNA has been detected in keratinocytes, small intestine epithelial cells, adrenal cells, macrophages, pancreas, skeletal muscle, liver, lung and peripheral blood mononuclear cells, IL-18 receptors have been identified only on T, B and NK cells. IL-18 is a pro-atherogenic cytokine associated with the development of CVD [23]. Indeed, the IL-18 expression is increased in human atherosclerotic plaques and associated with plaque destabilization [24]. In a mice model, recombinant IL-18 injection leads to an increase in atherosclerotic lesions, possibly through enhancement of an inflammatory response involving an IFN- $\boldsymbol{\gamma}$-dependent mechanism [25]. Elevated plasma IL-18 levels are present in a number of inflammatory diseases, including rheumatoid arthritis, Crohn's disease, atherosclerosis [26] and CKD [27]. IL-18 levels have been shown to be increased in predialysis, $\mathrm{HD}$ and peritoneal dialysis (PD) patients $[23,26,28,29]$. As increased production of IFN- $\gamma$ is one of the main characteristics of the Th1 response, IL-18 accumulation in uremic patients may contribute to such a response also in HD patients [26, 30]. A direct correlation between IL-18 levels and time on dialysis (dialysis vintage) was shown in both HD [28] and PD [23] patients, and may be ascribed to a chronic inflammatory state that progresses over time.

In stable and unstable angina patients, an elevated level of IL-18 was shown to be a strong predictor of cardiovascular mortality [31]. In HD patients, plasma IL-18 levels predicted hospitalization rate, but not mortality [32]. A similar finding was also shown in PD patients [23]. Indeed, the gain in prediction power to that of IL- 6 associated with the inclusion of IL-18 was small and nonsignificant [19]. Interestingly, a recent study reported that the IL-18 levels were higher in PD patients as compared to predialysis patients and HD patients [33]. Consistent with this finding, IL-18 has been shown to be protective during bacterial infections, and high IL-18 levels in peritoneal dialysate effluent during the early phase of peritonitis correlated with a predominant Th1 immune response and favorable outcome [34]. In light of these results, it could be speculated that local IL-18 production may be part of a protective early immune response to $\mathrm{PD}$ related peritonitis.

\section{Interleukin-12}

IL-12 is another pro-inflammatory cytokine that has a central function in the initiation and regulation of the cellular immune response. It has the capacity to regulate the differentiation of native T cells into Th1 cells, which is crucial in determining resistance and the type of response that will be elicited in response to a particular pathogen. IL-12 is produced early in the infectious process by activated macrophages and enhances the host innate resistance at the same time as shaping the ultimate antigen-specific immune response [35]. IL-12 plays an important role mediating the enhancement of the cytotoxic activity of NK cells and CD8+ cytotoxic T lymphocytes. There also seems to be a link between IL-2 and the signal transduction of IL-12 in NK cells. Because of their synergistic roles in stimulating inflammation, IL-12, IFN- $\gamma$ and TNF- $\alpha$ are considered to be major pro-inflammatory cytokines [11].

In general, IL-12 levels are increased in CKD patients with or without dialysis therapy [36-38], being involved in promoting a state of Th1 differentiation. In PD, local IL-12 production is part of a protective early immune response to peritonitis and correlates well with type $1 \mathrm{~T}$ cell polarization $[34,39]$. In HD, the production of IL-12 by macrophages and of IFN- $\gamma$ by Th1 cells seems to be higher as compared to controls [40]. Consequently, increased IL-12 levels were associated with improved survival in a large cohort of patients on dialysis [36]. However, the bioincompatibility of the HD procedure seems to play a role in IL-12 production which could worsen the uremic immunodeficiency, as HD patients dialyzed with cuprophan membranes have a lower IL-12 production than those using polymethylmethacrylate membranes or nondialyzed uremic patients [41].

\section{Interleukin-7 and Interleukin-15}

IL-7 is a hematopoietic growth factor - secreted by the stromal cells of the red marrow and thymus - capable of stimulating the proliferation of lymphoid progenitor cells. This cytokine is important for proliferation during certain stages of $\mathrm{B}$ cell maturation, and for $\mathrm{T}$ and $\mathrm{NK}$ cell survival, development and homeostasis. IL-15 is a cyto- 


\section{1}

Evaluate and treat co-morbidities that may cause inflammation

- Infectious complications

- Silent ischemic heart disease

- Intercurrent clinical events

- Peridontal disease

- Failed kidney transplant

- Volume overload

- Inflammatory diseases
2

Evaluate and treat potential dialysis-related causes of inflammation

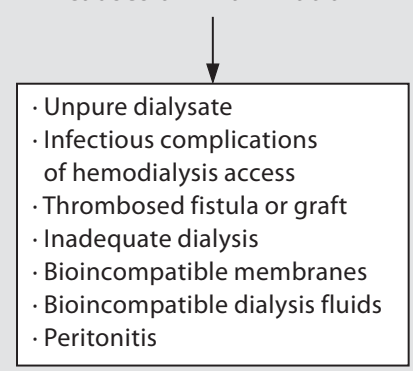

3

Consider

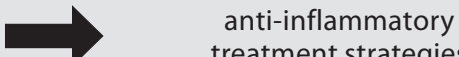

treatment strategies

- Nutritional intervention

- Physical training

- Pharmacological intervention

Fig. 1. Suggested steps to target persistent inflammation in CKD patients.

kine with structural similarity to IL-2 that is secreted mainly by mononuclear phagocytes following infection by viruses. This cytokine induces cell proliferation of NK cells; cells of the innate immune system whose principal role is to kill virally infected cells.

Plasma IL-7 concentrations have been reported to be decreased in CKD patients [42], which is interesting because virtually all the other cytokines seem to be increased in the uremic milieu [36]. This IL-7 deficiency has been related to lymphophenia in specific $\mathrm{T}$ cell subsets from CKD patients [42]. In isolated peripheral blood mononuclear cells (PBMCs) from HD patients the simultaneous stimulation with the combination TNF- $\alpha$ plus IL-15 appeared to be more potent than the stimulation of the cytokines alone [43]. Hausmann et al. [44] experimentally demonstrated that human peritoneal mesothelial cells (HPMCs) secrete IFN- $\gamma$, IL-2 and IL-15 upon antigen stimulation. Consequently, increased IL-15 levels were observed in effluents of PD patients suffering from peritonitis as compared to those free of peritonitis [44]. As IL-15 is a potent T cell activator [45], it is plausible that HPMCs may participate in the peritoneal immune response against invading pathogens by contributing to $\mathrm{T}$ cell activation through IL-15 secretion.

\section{Interleukin-8}

IL-8 is produced by macrophages and other cell types such as epithelial cells. When first encountering an antigen, macrophages are the first cells to respond, by phago- cyting the particle. Upon processing, they release primarily IL- 8 to signal to other immune cells to come to the site of inflammation. Thus, IL- 8 serves as a chemical signal to attract neutrophils at the site of inflammation, and therefore it is also known as neutrophil chemotactic factor. IL8 is a well-established pro-atherogenic cytokine [46]. In HD patients, IL-8 levels were dramatically increased, and constituted a powerful and independent predictive factor for cardiovascular and all-cause mortality [47]. As it has been suggested that anti-oxidant and reactive oxygen species (ROS) can up-regulate IL-8 gene expression [48], it is possible that the ROS up-regulation associated to HD contributes to the induction of IL-8 [49]. However, conflicting results exist to date, on whether a single HD session increases or decreases the concentration of IL-8 [50, 51]. Of interest, increasing doses of simvastatin to PBMC cultures from CKD patients induced a dose-dependent inhibition of both IL-6 and IL-8 [52, 53].

\section{Implications for Cytokine Treatment Strategies}

As the immune system is extremely complex and of great importance for maintaining homeostasis, urgent measures should be taken to counteract its deleterious effects (fig. 1). It should be logical to start by targeting the co-morbidities and dialytic processes that may cause inflammation (see below). Also, a number of putative antiinflammatory strategies are available (table 1). 


\section{Lifestyle and Nutritional Measures}

At first, given the documented associations between pro-inflammatory cytokines and lifestyle factors [54], appropriate lifestyle modifications, such as weight loss or exercise training [55], may be an important component in normalizing the dysregulated cytokine system activity in CKD [56]. Dietary interventions could also have an important role that has been, up to now, not enough explored. Because fish eaters have lower mortality on HD [57] and small studies in HD suggest that omega-3 fatty acids have a beneficial impact [58], the potential beneficial effects of fish oil or omega-3 fatty acids consumption merits further investigation in CKD patients. Of interest, a small randomized controlled trial with fish oil in HD patients found significant reductions in CRP concomitant with a rise in blood omega-3 levels [59]. Sex hormones may also be important for atheroprotection as men with low testosterone levels as well as women with low estrogen levels are at increased risk of CVD. The reported ability of sex hormones to interfere with cytokine production by repression of IL- 6 mRNA may contribute to such protective effects [60]. This may have implications for natural sex-hormone derivatives like the flavonoid genistein present in soy. In fact, a study on isoflavone soy intervention in $\mathrm{HD}$ patients could show inverse correlations between changes in serum isoflavone levels and CRP levels [61]. Finally, a number of other nutritional interventions, such as fiber-rich food, nuts, probiotics, and diets low in advanced glycation end-products may have anti-inflammatory properties and should be evaluated in CKD patients $[62,63]$.

\section{Unspecific Anti-Inflammatory Pharmacological \\ Interventions}

The role of unspecific anti-inflammatory pharmacological treatment strategies either alone or combined as a preventive therapy needs further evaluation. It is notable that several commonly used drugs may possess significant anti-inflammatory effects. Statins not only inhibit cholesterol synthesis but also showed anti-inflammatory actions [52, 64] and anti-oxidative properties [65] in HD patients. However, no effect on survival was demonstrated in the randomized controlled trial 4D [66]. In another study, IL-8, IL- 6 and TNF- $\alpha$ level were reduced during aspirin consumption in HD patients [67]. ACE inhibitor (ACEI) treatment is associated with a reduction in IL-6 response to coronary artery graft surgery [68]. In accordance, we have found lower plasma levels of TNF- $\alpha$, CRP [69] and adhesion molecules [70] in CKD patients treated by ACEI. Of interest, ACEI has also been shown to pre-
Table 1. Current status of anti-inflammatory treatment strategies in CKD patients

Current status as of 2008

I. Associated to dialysis treatment per se

\begin{tabular}{ll} 
Ultrapure dialysate & repeatedly shown to reduce CRP [90-93] \\
\hline $\begin{array}{l}\text { Biocompatible } \\
\text { membranes }\end{array}$ & $\begin{array}{l}\text { the inflammatory reaction is affected by } \\
\text { choice of dialyzer [94] }\end{array}$ \\
\hline Hemodiafiltration & $\begin{array}{l}\text { on-line HDF does not provoke the inflam- } \\
\text { matory response [95] }\end{array}$ \\
\hline Daily dialysis & $\begin{array}{l}\text { dramatic positive effect on CRP in one } \\
\text { study [96] }\end{array}$
\end{tabular}

\section{Nutritional and lifestyle interventions}

\begin{tabular}{ll}
\hline Physical training & $\begin{array}{l}\text { resistance training reduced inflammation } \\
\text { and improved nutritional status in CKD } \\
\text { patients on a low-protein diet [55] }\end{array}$ \\
\hline $\begin{array}{l}\text { Omega-3 fatty } \\
\text { acids }\end{array}$ & $\begin{array}{l}\text { 12-week fish oil supplementation decreases } \\
\text { CRP in HD patients [59] }\end{array}$ \\
\hline Soy & $\begin{array}{l}\text { lower prevalence of inflammation and bet- } \\
\text { ter outcome in Asian HD patients; soy sup- } \\
\text { plementation decreases CRP in HD pa- } \\
\text { tients [61] }\end{array}$
\end{tabular}

\section{Pharmacological interventions}

\begin{tabular}{ll}
\hline Statins & $\begin{array}{l}\text { no effect of atorvastatin on CRP in the 4D } \\
\text { study [Wanner, pers. commun., 2007] }\end{array}$ \\
\hline ACEI & $\begin{array}{l}\text { reduction in IL-6 response to coronary ar- } \\
\text { tery graft surgery [68]; lower inflammatory } \\
\text { [69] and adhesion molecules [70] in CKD } \\
\text { patients treated by ACEI. }\end{array}$ \\
\hline Sevelamer & $\begin{array}{l}\text { a small randomized study showed decrease } \\
\text { in CRP + increase in fetuin-A [75] }\end{array}$
\end{tabular}

Gamma-tocopherol small randomized trial in HD shows effect on IL-6 [83]

IL-1 antagonism promising results in diabetic [88] and gout [89] patients

$\mathrm{N}$-acetylcysteine small study shows effect on outcome in HD [97]

\begin{tabular}{ll}
\hline Heparin & $\begin{array}{l}\text { low-molecular-weight heparin reduces in- } \\
\text { flammation in HD patients [98] }\end{array}$ \\
\hline
\end{tabular}

Vitamin D encouraging data on reducing inflammation biomarkers in other patient groups [72] 
vent heart failure patients from wasting [71]. Other interesting approaches may include vitamin $\mathrm{D}$, which effectively reduced the inflammatory milieu in a randomized controlled trial performed in chronic heart failure patients [72]. This is pertinent to CKD patients too, as vitamin $\mathrm{D}$ deficiency has been shown to be rather common and associated to increased short-term mortality [73]. Sevelamer has also been suggested to exert favorable changes in lipids and inflammatory markers with potentially useful antiatherogenic effects in HD patients [74]. In addition, short-term sevelamer intake significantly increased fetuin A levels and improved flow-mediated dilation in nondiabetic stage 4 CKD patients [75]. Both vitamin $\mathrm{E}$ and $\mathrm{N}$-acetylcysteine, two natural antioxidants that may inhibit pro-inflammatory cytokine release [76, 77] and improve endothelial dysfunction [78, 79], have been shown to reduce cardiovascular events in rather small cohorts of dialysis patients [80, 81]. N-acetylcysteine is an especially interesting option to test considering its effect on reducing atheroma progression (probably via a decrease in oxidative stress) in an animal model of uremia-enhanced atherosclerosis [82]. Also, recent results from a randomized controlled trial with a combination of $\gamma$-tocopherol and docosahexaenoic acid (DHA) in HD patients showed a significant reduction in selected biomarkers of inflammation [83]. Finally, PPAR- $\gamma$ activators such as rosiglitazone may be another interesting strategy to explore given their anti-inflammatory effects in a group of PD patients [84]. However, as the myocardial ischemic risk associated with rosiglitazone treatment may be increased in type II diabetics patients [85], these drugs should be used with caution in dialysis patients.

\section{Targeted Anticytokine Interventions}

As targeted anticytokine treatment strategies have been shown to be effective in other patient groups with inflammation, these drugs may be of interest to study also in ESRD patients. Thalidomide, a drug with immunomodulatory, anti-inflammatory and antiangiogenic properties, exerts its therapeutic effects through the modulation of TNF- $\alpha$. As thalidomide induces a Th2 response and has been associated with weight gain in other wasted patient groups, such as those with HIV or tuberculosis [86], it would be of interest to test the effects of this drug in ESRD patients. Pentoxifylline was recently shown to reduce TNF- $\alpha$ expression by $>50 \%$ and to improve hemoglobin levels in HD patients with erythropoietin-resistant anemia [87]. Finally, results in type-2 diabetic patients [88] and in patients with acute gout [89] with interleukin-1-receptor antagonists have shown promising results.

\section{Acknowledgments}

The authors and some of the studies presented here were supported by grants from the ERA-EDTA, Karolinska Institutet Center for Gender-Based Research, the Swedish Medical Research Council, Martin Rind's Foundation, the General Export Association of Sweden, MEC (EX2006-1670) and the Heart and Lung Foundation. B.L. is employed by Baxter Healthcare Inc. P.S. is a member of the advisory board of Gambro.

\section{References}

1 Descamps-Latscha B, Herbelin A, Nguyen AT, Zingraff J, Jungers P, Chatenoud L: Immune system dysregulation in uremia. Semin Nephrol 1994;14:253-260.

-2 Descamps-Latscha B, Jungers P, Witko-Sarsat V: Immune system dysregulation in uremia: role of oxidative stress. Blood Purif 2002;20:481-484.

3 Carrero JJ, Axelsson J, Avesani CM, Heimburger O, Lindholm B, Stenvinkel P: Being an inflamed peritoneal dialysis patient: a Dante's journey. Contrib Nephrol. Basel, Karger, 2006, vol 150, pp 144-151.

-4 Pereira BJ, Snodgrass B, Barber G, Perella C, Chopra S, King AJ: Cytokine production during in vitro hemodialysis with new and formaldehyde- or renalin-reprocessed cellulose dialyzers. J Am Soc Nephrol 1995;6: 1304-1308.
5 Don BR, Kaysen GA: Assessment of inflammation and nutrition in patients with endstage renal disease. J Nephrol 2000;13:249259.

6 Lo WK: Serum parameters, inflammation, renal function and patient outcome. Contributions to nephrology 2006;150:152-155.

-7 Chung SH, Heimburger O, Lindholm B, Stenvinkel P: Chronic inflammation in PD patients. Contrib Nephrol 2003:104-111.

$\checkmark 8$ Avesani CM, Carrero JJ, Axelson J, Qureshi AR, Lindholm B, Stenvinkel P: Inflammation and wasting in chronic kidney disease: partners in crime. Kidney Int 2006;70:S8S13.
9 Stenvinkel P, Wanner C, Metzger T, Heimburger O, Mallamaci F, Tripepi G, Malatino L, Zoccali C: Inflammation and outcome in end-stage renal failure: does female gender constitute a survival advantage? Kidney Int 2002;62:1791-1798.

10 Elenkov IJ, Iezzoni DG, Daly A, Harris AG, Chrousos GP: Cytokine dysregulation, inflammation and well-being. Neuroimmunomodulation 2005; 12:255-269.

11 Fearon DT, Locksley RM: The instructive role of innate immunity in the acquired immune response. Science 1996;272:50-53.

12 Frostegard J, Ulfgren AK, Nyberg P, Hedin U, Swedenborg J, Andersson U, Hansson GK: Cytokine expression in advanced human atherosclerotic plaques: dominance of proinflammatory (Th1) and macrophage-stimulating cytokines. Atherosclerosis 1999;145: 33-43. 
13 Stenvinkel P, Ketteler M, Johnson RJ, Lindholm B, Pecoits-Filho R, Riella M, Heimburger O, Cederholm T, Girndt M: IL-10, IL6, and TNF-alpha: central factors in the altered cytokine network of uremia - the good, the bad, and the ugly. Kidney Int 2005; 67:1216-1233.

-14 Sester U, Sester M, Hauk M, Kaul H, Kohler H, Girndt M: T-cell activation follows Th1 rather than Th2 pattern in haemodialysis patients. Nephrol Dial Transplant 2000;15: 1217-1223.

-15 Libetta C, Rampino T, Dal Canton A: Polarization of T-helper lymphocytes toward the Th2 phenotype in uremic patients. Am J Kidney Dis 2001;38:286-295.

$\checkmark 16$ Coppo R, Amore A: Importance of the bradykinin-nitric oxide synthase system in the hypersensitivity reactions of chronic haemodialysis patients. Nephrol Dial Transplant 2000; 15:1288-1290.

- 17 Stenvinkel P, Barany P, Heimburger O, Pecoits-Filho R, Lindholm B: Mortality, malnutrition, and atherosclerosis in ESRD: what is the role of interleukin-6? Kidney Int Suppl 2002;62:103-108.

- 18 Honda H, Qureshi AR, Heimburger O, Barany $\mathrm{P}$, Wang $\mathrm{K}$, Pecoits-Filho $\mathrm{R}$, Stenvinkel P, Lindholm B: Serum albumin, c-reactive protein, interleukin 6 , and fetuin a as predictors of malnutrition, cardiovascular disease, and mortality in patients with ESRD. Am J Kidney Dis 2006;47:139-148.

-19 Tripepi G, Mallamaci F, Zoccali C: Inflammation markers, adhesion molecules, and all-cause and cardiovascular mortality in patients with ESRD: searching for the best risk marker by multivariate modeling. J Am Soc Nephrol 2005;16(suppl 1):S83-S88.

-20 Zoccali C, Tripepi G, Mallamaci F: Dissecting inflammation in ESRD: do cytokines and c-reactive protein have a complementary prognostic value for mortality in dialysis patients? J Am Soc Nephrol 2006;17:S169_ S173.

-21 Pachaly MA, do Nascimento MM, Suliman ME, Hayashi SY, Riella MC, Manfro RC, Stenvinkel P, Lindholm B: Interleukin-6 is a better predictor of mortality as compared to c-reactive protein, homocysteine, pentosidine and advanced oxidation protein products in hemodialysis patients. Blood Purif 2008;26:204-210

-22 Matsumoto S, Tsuji-Takayama K, Aizawa Y, Koide K, Takeuchi M, Ohta T, Kurimoto M: Interleukin-18 activates NF-kappaB in murine $\mathrm{T}$ helper type 1 cells. Biochem Biophys Res Commun 1997;234:454-457.

-23 Yano A, Nakao K, Sarai A, Akagi S, Kihara T, Morimoto H, Nakamura A, Hiramatsu M, Nagake Y, Makino H: Elevated serum interleukin-18 levels might reflect the high risk of hospitalization in patients on peritoneal dialysis. Nephrology (Carlton) 2005;10:576582 .
24 Mallat Z, Corbaz A, Scoazec A, Besnard S, Leseche G, Chvatchko Y, Tedgui A: Expression of interleukin-18 in human atherosclerotic plaques and relation to plaque instability. Circulation 2001;104:1598-1603.

25 Whitman SC, Ravisankar P, Daugherty A: Interleukin-18 enhances atherosclerosis in apolipoprotein $\mathrm{E}(-/-)$ mice through release of interferon-gamma. Circ Res 2002;90: E34-E38.

26 Chiang CK, Hsu SP, Pai MF, Peng YS, Ho TI, Liu SH, Hung KY, Tsai TJ, Hsieh BS: Plasma interleukin-18 levels in chronic renal failure and continuous ambulatory peritoneal dialysis. Blood Purif 2005;23:144-148.

27 Girndt M, Sester U, Kaul H, Kohler H: Production of proinflammatory and regulatory monokines in hemodialysis patients shown at a single-cell level. J Am Soc Nephrol 1998; 9:1689-1696.

28 Gangemi S, Mallamace A, Minciullo PL, Santoro D, Merendino RA, Savica V, Bellinghieri G: Involvement of interleukin-18 in patients on maintenance haemodialysis. Am J Nephrol 2002;22:417-421.

29 Uchimura T, Motomiya Y, Okamura $\mathrm{H}$ Hashiguchi T, Miura M, Uji Y, Iwamoto H, Maruyama I: Marked increases in macrophage colony-stimulating factor and interleukin-18 in maintenance hemodialysis patients: comparative study of advanced glycation end products, carboxymethyllysine and pentosidine. Nephron 2002;90:401407.

30 Descamps-Latscha B: The immune system in end-stage renal disease. Curr Opin Nephrol Hypertens 1993;2:883-891.

-31 Blankenberg S, Tiret L, Bickel C, Peetz D, Cambien F, Meyer J, Rupprecht HJ: Interleukin-18 is a strong predictor of cardiovascular death in stable and unstable angina. Circulation 2002;106:24-30.

32 Chiang CK, Hsu SP, Pai MF, Peng YS, Ho TI, Liu SH, Hung KY, Tsai TJ: Interleukin-18 is a strong predictor of hospitalization in haemodialysis patients. Nephrol Dial Transplant 2004;19:2810-2815.

33 Wong CK, Szeto CC, Chan MH, Leung CB Li PK, Lam CW: Elevation of pro-inflammatory cytokines, c-reactive protein and cardiac troponin $\mathrm{T}$ in chronic renal failure patients on dialysis. Immunological investigations 2007;36:47-57.

34 Wang $\mathrm{HH}$, Lin CY: Interleukin-12 and -18 levels in peritoneal dialysate effluent correlate with the outcome of peritonitis in patients undergoing peritoneal dialysis: implications for the type I/type II T-cell immune response. Am J Kidney Dis 2005;46:328338.

35 Watford WT, Moriguchi M, Morinobu A, O'Shea JJ: The biology of IL-12: coordinating innate and adaptive immune responses. Cytokine Growth Factor Rev 2003;14:361-368.
36 Kimmel PL, Phillips TM, Simmens SJ, Peterson RA, Weihs KL, Alleyne S, Cruz I, Yanovski JA, Veis JH: Immunologic function and survival in hemodialysis patients. Kidney Int 1998;54:236-244.

37 Ishizuka T, Nitta K, Yokoyama T, Hayashi T, Futatsuyama K, Kimata N, Miwa N, Nishida E, Kawashima A, Akiba T, Nihei H: Increased serum levels of interleukin-12 may be associated with th 1 differentiation in hemodialysis patients. Nephron 2002;90:503-504.

38 Nairn J, Hodge G, Henning P: Intracellular cytokines in peripheral blood leucocytes in children with chronic renal failure. Pediatr Nephrol 2006;21:251-256.

-39 Steinhauser ML, Hogaboam CM, Lukacs NW, Strieter RM, Kunkel SL: Multiple roles for IL-12 in a model of acute septic peritonitis. J Immunol 1999;162:5437-5443.

40 Daichou Y, Kurashige S, Hashimoto S, Suzuki S: Characteristic cytokine products of th1 and th2 cells in hemodialysis patients. Nephron 1999;83:237-245.

41 Memoli B, Marzano L, Bisesti V, Andreucci M, Guida B: Hemodialysis-related lymphomononuclear release of interleukin-12 in patients with end-stage renal disease. J Am Soc Nephrol 1999; 10:2171-2176.

42 Litjens NH, van Druningen CJ, Betjes MG: Progressive loss of renal function is associated with activation and depletion of naive $\mathrm{T}$ lymphocytes. Clin Immunol 2006;118:8391.

43 van Riemsdijk IC, Baan CC, Loonen EH, Zietse R, Weimar W: Patients on chronic hemodialysis have no intrinsic lymphocyte defect upon stimulation with interleukin-2, interleukin-15 or tumor necrosis factor-alpha. Blood Purif 2003;21:158-162.

-44 Hausmann MJ, Rogachev B, Weiler M, Chaimovitz C, Douvdevani A: Accessory role of human peritoneal mesothelial cells in antigen presentation and T-cell growth. Kidney Int 2000;57:476-486.

45 Tagaya Y, Bamford RN, DeFilippis AP, Waldmann TA: IL-15: a pleiotropic cytokine with diverse receptor/signaling pathways whose expression is controlled at multiple levels. Immunity 1996;4:329-336.

$\checkmark 46$ Reape TJ, Groot PH: Chemokines and atherosclerosis. Atherosclerosis 1999;147:213225.

47 Panichi V, Taccola D, Rizza GM, Consani C, Ghiadoni L, Filippi C, Cristofani R, Panicucci E, Migliori M, Sidoti A, Biagioli M, Boracelli D, Barsotti G, Tetta C: Interleukin-8 is a powerful prognostic predictor of all-cause and cardiovascular mortality in dialytic patients. Nephron Clin Pract 2006;102:c51c58.

48 DeForge LE, Fantone JC, Kenney JS, Remick DG: Oxygen radical scavengers selectively inhibit interleukin 8 production in human whole blood. J Clin Invest 1992;90:21232129 . 
-49 Friedrich B, Alexander D, Janessa A, Haring HU, Lang F, Risler T: Acute effects of hemodialysis on cytokine transcription profiles: evidence for c-reactive protein-dependency of mediator induction. Kidney Int 2006;70: 2124-2130.

-50 Tarakcioglu M, Erbagci AB, Usalan C, Deveci $R$, Kocabas R: Acute effect of hemodialysis on serum levels of the proinflammatory cytokines. Mediators Inflamm 2003;12: 15-19.

51 Rysz J, Banach M, Cialkowska-Rysz A, Stolarek R, Barylski M, Drozdz J, Okonski P: Blood serum levels of IL-2, IL-6, IL-8, TNFalpha and IL-1beta in patients on maintenance hemodialysis. Cell Mol Immunol 2006;3:151-154.

- 52 Panichi V, Paoletti S, Mantuano E, MancaRizza G, Filippi C, Santi S, Taccola D, Donadio C, Tramonti G, Innocenti M, Casto G, Consani C, Sbragia G, Franzoni F, Galetta F, Panicucci E, Barsotti G: In vivo and in vitro effects of simvastatin on inflammatory markers in pre-dialysis patients. Nephrol Dial Transplant 2006;21:337-344.

-53 Mantuano E, Santi S, Filippi C, Manca-Rizza G, Paoletti S, Consani C, Giovannini L, Tramonti G, Carpi A, Panichi V: Simvastatin and fluvastatin reduce interleukin- 6 and interleukin-8 lipopolysaccharide (LPS) stimulated production by isolated human monocytes from chronic kidney disease patients. Biomed Pharmacother 2007;61:360-365.

-54 Gielen S, Adams V, Mobius-Winkler S, Linke A, Erbs S, Yu J, Kempf W, Schubert A, Schuler G, Hambrecht R: Anti-inflammatory effects of exercise training in the skeletal muscle of patients with chronic heart failure. J Am Coll Cardiol 2003;42:861-868.

-55 Castaneda C, Gordon PL, Uhlin KL, Levey AS, Kehayias JJ, Dwyer JT, Fielding RA, Roubenoff R, Singh MF: Resistance training to counteract the catabolism of a low-protein diet in patients with chronic renal insufficiency: a randomized, controlled trial. Ann Intern Med 2001;135:965-976.

56 Castaneda C, Gordon PL, Parker RC, Uhlin KL, Roubenoff R, Levey AS: Resistance training to reduce the malnutrition-inflammation complex syndrome of chronic kidney disease. Am J Kidney Dis 2004;43:607-616.

- 57 Friedman AN, Moe SM, Perkins SM, Li Y, Watkins BA: Fish consumption and omega-3 fatty acid status and determinants in longterm hemodialysis. Am J Kidney Dis 2006; 47:1064-1071.

58 Friedman A, Moe S: Review of the effects of omega-3 supplementation in dialysis patients. Clin J Am Soc Nephrol 2006;1:182192.

59 Saifullah A, Watkins BA, Saha C, Li Y, Moe SM, Friedman AN: Oral fish oil supplementation raises blood omega-3 levels and lowers c-reactive protein in haemodialysis patients: a pilot study. Nephrol Dial Transplant 2007;22:3561-3567.
60 Ershler WB, Keller ET: Age-associated increased interleukin- 6 gene expression, latelife diseases, and frailty. Ann Rev Med 2000; 51:245-270.

61 Fanti P, Asmis R, Stephenson TJ, Sawaya BP, Franke AA: Positive effect of dietary soy in esrd patients with systemic inflammation: correlation between blood levels of the soy isoflavones and the acute-phase reactants. Nephrol Dial Transplant 2006;21:22392246

62 Stenvinkel P, Lindholm B, Heimburger O: Novel approaches in an integrated therapy of inflammatory-associated wasting in endstage renal disease. Semin Dialy 2004; 17 : 505-515.

63 Bengmark S: Bioecologic control of inflammation and infection in critical illness. Anesthesiol Clin 2006;24:299-323.

64 Vernaglione L, Cristofano C, Muscogiuri P, Chimienti S: Does atorvastatin influence serum c-reactive protein levels in patients on long-term hemodialysis? Am J Kidney Dis 2004;43:471-478.

65 Stenvinkel P, Rodriguez-Ayala E, Massy ZA, Qureshi AR, Barany P, Fellstrom B, Heimburger $\mathrm{O}$, Lindholm B, Alvestrand A: Statin treatment and diabetes affect myeloperoxidase activity in maintenance hemodialysis patients. Clin J Am Soc Nephrol 2006;1:281287.

66 Wanner C, Krane V, Marz W, Olschewski M, Mann JF, Ruf G, Ritz E: Atorvastatin in patients with type 2 diabetes mellitus undergoing hemodialysis. N Engl J Med 2005;353: 238-248.

67 Goldstein SL, Leung JC, Silverstein DM: Pro- and anti-inflammatory cytokines in chronic pediatric dialysis patients: effect of aspirin. Clin J Am Soc Nephrol 2006;1:979_ 986.

68 Brull DJ, Sanders J, Rumley A, Lowe GD, Humphries SE, Montgomery HE: Impact of angiotensin converting enzyme inhibition on post-coronary artery bypass interleukin 6 release. Heart (British Cardiac Society) 2002; 87:252-255.

69 Stenvinkel P, Andersson P, Wang T, Lindholm B, Bergstrom J, Palmblad J, Heimburger $\mathrm{O}$, Cederholm T: Do ACE-inhibitors suppress tumour necrosis factor-alpha production in advanced chronic renal failure? J Int Med 1999;246:503-507.

-70 Suliman ME, Qureshi AR, Heimburger O, Lindholm B, Stenvinkel P: Soluble adhesion molecules in end-stage renal disease: a predictor of outcome. Nephrol Dial Transplant 2006;21:1603-1610.

-71 Anker SD, Negassa A, Coats AJ, Afzal R, Poole-Wilson PA, Cohn JN, Yusuf S: Prognostic importance of weight loss in chronic heart failure and the effect of treatment with angiotensin-converting-enzyme inhibitors: an observational study. Lancet $2003 ; 361$ : 1077-1083.
72 Schleithoff SS, Zittermann A, Tenderich G, Berthold HK, Stehle P, Koerfer R: Vitamin d supplementation improves cytokine profiles in patients with congestive heart failure: A double-blind, randomized, placebo-controlled trial. Am J Clin Nutr 2006;83:754759 .

73 Wolf M, Shah A, Gutierrez O, Ankers E, Monroy M, Tamez H, Steele D, Chang Y, Camargo CA Jr, Tonelli M, Thadhani R: Vitamin D levels and early mortality among incident hemodialysis patients. Kidney Int 2007;72:1004-1013.

74 Ferramosca E, Burke S, Chasan-Taber S, Ratti C, Chertow GM, Raggi P: Potential antiatherogenic and anti-inflammatory properties of sevelamer in maintenance hemodialysis patients. Am Heart J 2005; 149: $820-825$

75 Kaglar K, Yilmaz MI, Saglam M, Cakir E, Acikel C, Eyileten T, Yenicesu M, Oguz Y, Vural A, Carrero JJ, Axelsson J, Lindholm B, Stenvinkel P: Short-term treatment with sevelamer increases serum fetuin-A concentration and improves endothelial dysfunction in chronic kidney disease stage 4 patients. Clin J Am Soc Nephrol; in press.

76 Lappas M, Permezel M, Rice GE: N-acetylcysteine inhibits phospholipid metabolism, proinflammatory cytokine release, protease activity, and nuclear factor-kappab deoxyribonucleic acid-binding activity in human fetal membranes in vitro. J Clinl Endocrinol Metab 2003;88:1723-1729.

-77 Jiang Q, Elson-Schwab I, Courtemanche C, Ames BN: Gamma-tocopherol and its major metabolite, in contrast to alpha-tocopherol, inhibit cyclooxygenase activity in macrophages and epithelial cells. Proc Natl Acad Sci USA 2000;97:11494-11499.

78 Scholze A, Rinder C, Beige J, Riezler R, Zidek W, Tepel M: Acetylcysteine reduces plasma homocysteine concentration and improves pulse pressure and endothelial function in patients with end-stage renal failure. Circulation 2004;109:369-374.

-79 Kinlay S, Fang JC, Hikita H, Ho I, Delagrange DM, Frei B, Suh JH, Gerhard M, Creager MA, Selwyn AP, Ganz P: Plasma alpha-tocopherol and coronary endothelium-dependent vasodilator function. Circulation 1999;100:219-221.

-80 Tepel M, van der Giet M, Statz M, Jankowski J, Zidek W: The antioxidant acetylcysteine reduces cardiovascular events in patients with end-stage renal failure: a randomized, controlled trial. Circulation 2003;107:992995.

81 Boaz M, Smetana S, Weinstein T, Matas Z, Gafter U, Iaina A, Knecht A, Weissgarten Y, Brunner D, Fainaru M, Green MS: Secondary prevention with antioxidants of cardiovascular disease in end-stage renal disease (space): randomised placebo-controlled trial. Lancet 2000;356:1213-1218. 
82 Ivanovski O, Szumilak D, Nguyen-Khoa T, Ruellan N, Phan O, Lacour B, DescampsLatscha B, Drueke TB, Massy ZA: The antioxidant $\mathrm{N}$-acetylcysteine prevents accelerated atherosclerosis in uremic apolipoprotein E knockout mice. Kidney Int 2005; 67:2288-2294.

83 Himmelfarb J, Phinney S, Ikizler TA, Kane J, McMonagle E, Miller G: Gamma-tocopherol and docosahexaenoic acid decrease inflammation in dialysis patients. J Ren Nutr 2007; 17:296-304.

-84 Wong TY, Szeto CC, Chow KM, Leung CB, Lam CW, Li PK: Rosiglitazone reduces insulin requirement and c-reactive protein levels in type 2 diabetic patients receiving peritoneal dialysis. Am J Kidney Dis 2005;46:713719.

-85 Nissen SE, Wolski K: Effect of rosiglitazone on the risk of myocardial infarction and death from cardiovascular causes. N Engl J Med 2007;356:2457-2471.

86 Haslett PA: Anticytokine approaches to the treatment of anorexia and cachexia. Semin Oncol 1998;25:53-57.

-87 Cooper A, Mikhail A, Lethbridge MW, Kemeny DM, Macdougall IC: Pentoxifylline improves hemoglobin levels in patients with erythropoietin-resistant anemia in renal failure. J Am Soc Nephrol 2004;15:18771882.
88 Larsen CM, Faulenbach M, Vaag A, Volund A, Ehses JA, Seifert B, Mandrup-Poulsen T, Donath MY: Interleukin-1-receptor antagonist in type 2 diabetes mellitus. N Engl J Med 2007;356:1517-1526.

89 So A, De Smedt T, Revaz S, Tschopp J: A pilot study of IL-1 inhibition by anakinra in acute gout. Arthritis Res Ther 2007;9:R28.

90 Lonnemann G: When good water goes bad: how it happens, clinical consequences and possible solutions. Blood Purif 2004;22:124129.

91 Schindler R, Beck W, Deppisch R, Aussieker M, Wilde A, Gohl H, Frei U: Short bacterial DNA fragments: detection in dialysate and induction of cytokines. J Am Soc Nephrol 2004; 15:3207-3214.

92 Sitter T, Bergner A, Schiffl H: Dialysate related cytokine induction and response to recombinant human erythropoietin in haemodialysis patients. Nephrol Dial Transpl 2000;15:1207-1211.

-93 Schiffl H, Lang SM, Stratakis D, Fisher R: Effects of ultrapure dialysis fluid on nutritional status and inflammatory parameters. Nephrol Dial Transpl 2001;16:1863-1869.
94 Schindler R, Boenisch O, Fischer C, Frei U: Effect of the hemodialysis membrane on the inflammatory reaction in vivo. Clin Nephrol 2000;53:452-459.

$>95$ Vaslaki LR, Berta K, Major L, Weber V, Weber C, Wojke R, Passlick-Deetjen J, Falkenhagen $\mathrm{D}$ : On-line hemodiafiltration does not induce inflammatory response in end-stage renal disease patients: results from a multicenter cross-over study. Artific Organs 2005; 29:406-412.

$\$ 6$ Ayus JC, Mizani MR, Achinger SG, Thadhani R, Go AS, Lee S: Effects of short daily versus conventional hemodialysis on left ventricular hypertrophy and inflammatory markers: a prospective, controlled study. J Am Soc Nephrol 2005;16:2778-2788.

97 Tepel M: Acetylcysteine for the prevention of radiocontrast-induced nephropathy. Minerva Cardioangiol 2003;51:525-530.

$\checkmark 98$ Poyrazoglu OK, Dogukan A, Yalniz M, Seckin D, Gunal AL: Acute effect of standard heparin versus low molecular weight heparin on oxidative stress and inflammation in hemodialysis patients. Renal Failure 2006; 28:723-727 